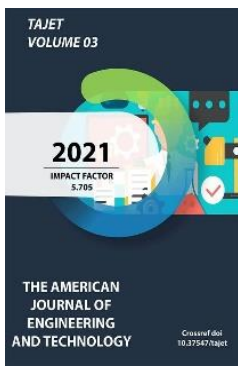

Copyright: Original content from this work may be used under the terms of the creative commons attributes 4.0 licence.

\section{Study Of The Influence Of Light Weather On The Mechanical Properties Of Para-Aramid Filaments}

\author{
S. J. Razzakov \\ Doctor Of Technical Sciences, Professor, Namangan Civil Engineering Institute, Namangan, \\ Uzbekistan \\ B. K. Rakhmanov \\ PhD, Fergana Polytechnic Institute, Fergana, Uzbekistan \\ J.D. Akhmedov \\ Candidate Of Technical Sciences, Associate Professor, Fergana Polytechnic Institute, Fergana, \\ Uzbekistan
}

\title{
ABSTRACT
}

The article presents the prospects for the growth of construction volumes in the Republic of Uzbekistan, as a consequence of the need for load-handling devices (LHD) made of synthetic woven belts and ropes (STLK). The results of experimental work are presented, where the wear of textile materials after exposure to light weather is characterized by a change in mechanical properties, which affects the reliability of products during operation.

\section{KEYWORDS}

Technology of construction processes, lifting and transport equipment, lifting device, rigging, textile sling, light weather, para-aramid threads.

\section{INTRODUCTION}

Scientists began to deal with the use of synthetic textile products in engineering and technology from the middle of the last century when the high strength of synthetic materials was discovered by molecular chemistry. In the USA, developed countries of Europe and in the 
Russian Federation, studies were carried out to study the application of high-strength textile synthetic materials in various industries [1].

Due to the appearance on the market of inexpensive textile slings made of polyester or polypropylene woven belts, the industry has mastered the production of modern reusable slinging devices and cargo tensioning belts. These materials are resistant to moisture, heat, light, have high frost resistance, are not affected by chemicals, oils and organic solvents. The main advantage of textile belts and ropes is a small mass, they do not intertwine and do not entangle with each other, wear-resistant, easily cleaned when dirty, capable of withstanding loads up to 100 tons, and this makes them indispensable for slinging or securing heavy loads, without damaging surface [2].

In some cases, they are the only possible device for strapping and slinging cargo. To a greater extent, this applies to goods that need careful handling [3].
In Uzbekistan, certain steps are being taken in the field of production and use of STLK. Belts are produced, but they are used for various needs of management, their indicators are little researched, not tested and not certified, and even more so they are not intended for lifting devices. There is also no regulatory framework for the production and use of these products [4].

The production of textile slings begins with the manufacture of synthetic fibres and threads, which, in addition to slings, have many other practical applications. As a raw material for the production of ribbons, multifilament and paraaramid threads are widely used based on synthetic high molecular weight (HMW) materials presented in Table 1. All of these synthetic materials have certain physical and chemical properties. This determines the characteristics and scope of synthetic belts and ropes.

Table 1. Multifilament and para-aramid threads based on synthetic high molecular weight (HMW) materials

\begin{tabular}{|c|c|c|c|}
\hline No & Material & Short title & Other names, brands, country manufacturer \\
\hline 1 & 2 & 3 & 4 \\
\hline 1 & Polyamide & ПA, PA (eng) & Nylon, Kapron. \\
\hline 2 & Polyester & PET, PES & HMW Russia \\
\hline 3 & Polypropylene & PP & Rusar C, Ruslan - Russia \\
\hline 4 & Polyethylene & PE & $\begin{array}{c}\text { Kevlar-USA, Technora-Japan, Twaron-Netherlands, } \\
\text { etc. }\end{array}$ \\
\hline 5 & Aramid & PPTA & Spektra-Germany, Dunema-US, Trevo-Sweden, etc. \\
\hline 6 & $\begin{array}{c}\text { High molecular } \\
\text { weight }\end{array}$ & HMPE, HPPE & \\
\hline
\end{tabular}


Para-aramid yarns of production are widely used: - Russian (SVM, Rusar); foreign (twaron, technor). Artificial fibres - nylon, lavsan in foreign terminology are called - nylon (polyamide, polypropylene), dacron (polyester, polyester) and kevlar [3]. Of these polymers, local raw materials are polypropylene and polyethylene produced by the UGCC [5]. Over time, synthetic slings lose their strength from the "ageing" of the material, which depends: - on the oxidation process under the influence of oxygen in the air; -from the action of sunlight; - from the action of ultraviolet sunlight; - and as an additional activator - against high temperatures. Oxidation of polymers with molecular oxygen is one of the most common chemical reactions that cause the ageing of polymers and failure of products. Oxidation is accelerated by several chemicals and physical factors, especially thermal effects.

In the conditions of Uzbekistan, construction is carried out in temperature ranges from $-20^{\circ}$ to $+50^{\circ}$, while various materials in direct sunlight are heated to $70-80^{\circ} \mathrm{C}$.

With the intensive use of synthetic textile slings with various connecting elements, limit switches, rollers, shafts and other contact surfaces, these conditions should be taken into account as the action of external friction forces [4].

UV stabilizers solve the problems of lightfastness, chemical resistance under the influence of radiation with a length of 320-400 nanometres. When using UV stabilizers, the service life of polymer products is increased. UV stabilizers are used to stabilize a wide range of polymers - PP, PS, PA, PC, PET, etc.

There are two ways to use UV stabilizers: coating of the finished product, introduction into the polymer during production. Hindered amines, benzophenone derivatives, inorganic pigments (carbon black, titanium dioxide, zinc sulfide), salicylic acid derivatives are used as a base. The UV stabilizer must be well dissolved in the polymer, possess the required volatility, high concentration (10\% and 20\%), and not migrate from the polymer when heated. The percentage of input of UV stabilizers is calculated individually depending on the region of use of the product, the amount of solar radiation. Table 2 the effect of ultraviolet radiation on synthetic threads is presented.

Table 2. Influence of ultraviolet radiation on synthetic threads

\begin{tabular}{|c|c|c|}
\hline $\begin{array}{c}\text { No } \\
\mathrm{p} / \mathrm{p}\end{array}$ & Material & UV resistance, on a scale of 1 to 10 \\
\hline 1 & 2 & 3 \\
\hline 1 & Polyamide & 8 \\
\hline 2 & Polyester & 10 \\
\hline 3 & Polyropylene & 6 \\
\hline 4 & Polyethylene & 9 \\
\hline 5 & High molecular weight polyethylene & 9 \\
\hline
\end{tabular}

If finished slings are treated with special compounds and covered with light-stabilizing coatings, then the ratios presented in Table 2. may vary. High-strength and high-modulus 
para-aramid yarns produced in Russia (terlon and lavsan), the USA (Kevlar) and the Netherlands (twaron) [5] were selected as objects of research. The wear of textile materials after exposure to light weather is characterized by a change in mechanical properties, which affects the reliability of products during operation. The breaking characteristics of the threads were determined in accordance with $[6,10]$.
The results of measuring the breaking characteristics of the threads are given in the table. 3. In accordance with the data table. 3, the value of the breaking characteristics of the threads decreases with an increase in the duration of exposure to light weather, and the greatest drop in breaking load is observed in the terlon SB thread, and the breaking elongation - in the Kevlar thread.

Table 3. Breaking characteristics of threads

\begin{tabular}{|c|c|c|c|}
\hline Time, $\mathrm{h}$ & $\begin{array}{c}\text { Specific } \\
\text { breaking load } \\
\text { Ro, N/tex }\end{array}$ & $\begin{array}{l}\text { Relative breaking } \\
\text { elongation } \varepsilon_{\rho}, \%\end{array}$ & The work of the gap Rr, J \\
\hline \multicolumn{4}{|c|}{ Lavsan } \\
\hline 0 & 0,38 & 12,85 & 4,78 \\
\hline 6 & 0,54 & 12,33 & 4,53 \\
\hline 12 & 0,56 & 12,04 & 4,10 \\
\hline 18 & 0,53 & 11,35 & 3,98 \\
\hline 24 & 0,56 & 10,53 & 3,24 \\
\hline \multicolumn{4}{|c|}{ Terlon Sat } \\
\hline 0 & 1,15 & 2,28 & 1,30 \\
\hline 6 & 1,00 & 2,22 & 0,95 \\
\hline 12 & 0,86 & 2,15 & 0,76 \\
\hline 18 & 0,87 & 2,08 & 0,72 \\
\hline 24 & 0,64 & 1,38 & 0,31 \\
\hline \multicolumn{4}{|c|}{ Kevlar } \\
\hline 0 & 1,2 & 7,28 & 9,07 \\
\hline 6 & 0,76 & 6,09 & 8,10 \\
\hline 12 & 0,76 & 4,90 & 6,34 \\
\hline 18 & 0,82 & 2,61 & 6,22 \\
\hline 24 & 0,82 & 1,47 & 4,76 \\
\hline \multicolumn{4}{|c|}{ Tvaron 1000} \\
\hline 0 & 1,09 & 6,47 & 7,13 \\
\hline 6 & 0,97 & 4,50 & 6,25 \\
\hline 12 & 0,95 & 4,47 & 5,74 \\
\hline 18 & 0,69 & 2,35 & 2,86 \\
\hline 24 & 0,74 & 1,95 & 0,74 \\
\hline
\end{tabular}

The stretching process is well described by tensile diagrams, where the sample elongation is plotted along the abscissa axis, and breaking load along the ordinate axis. Stretching curves can be divided into three types $[5,8]$.
During the tests, tensile diagrams of the investigated filaments were obtained, the appearance of which can explain the nature of the high physicomechanical properties of paraaramids, since their properties are determined 
The American Journal of Engineering and Technology (ISSN - 2689-0984

Published: April 25, 2021 | Pages: 35-41

Doi: https://doi.org/10.37547/tajet/Volume03Issue04-06

by the structure of the initial polymer or copolymer [9].
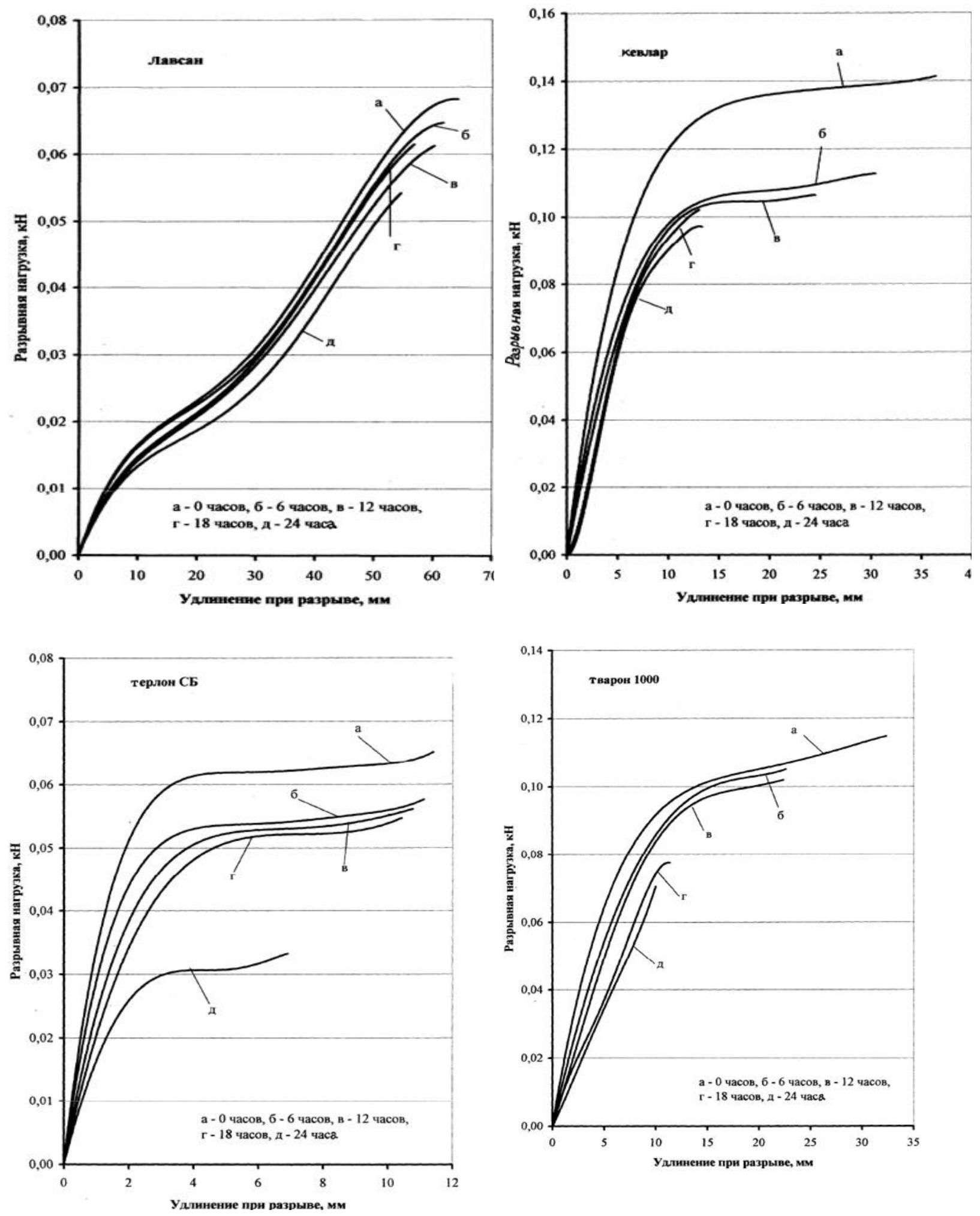
Fig. 1. The diagrams of load - elongation at break of threads exposed for 6, 12, 18 and 24 hours are presented [5].

When the structural elements are less oriented, or slightly straightened, or interact less strongly, curves of the second type are obtained. They are typical for Kevlar (Fig. 1.2), Terlon SB (Fig. 1.3), Twaron 1000 (Fig. 1.4). Lavsan threads (Fig. 1) belong to curves of the third type (S-shaped curves). The formation of curves of the third type is explained by the fact that in the fibres and filaments at the beginning of stretching, the orientation of their particles continues, then the structure stabilizes, and a section appears that resembles a curve of the first type. At the end of stretching, the existing structure is destroyed and a new one is created (recrystallization), as a result of which the deformation greatly increases with a relatively small force. In conclusion, it can be noted that para-aramid threads have initial high mechanical properties, the effect of light weather has a significant effect on them, which leads to their destruction, and, consequently, to a decrease in the quality of products made from these threads.

\section{REFERENCES}

1. Suleymanova, L. A., Raxmanov, B. K., Kocherjenko, V. V., \& Solodov, N. V. (2018). Perspektivnye napravlenija razvitija tehnologii takelazhnyh rabot s ispol'zovaniem stropov na tekstil'noj osnove. [Perspective directions of development of the technology of rigging with the use of slings on a textile basis.]. Bulletin of the Belgorod State Technological University named after VG Shukhov, (7). (in Russian)
2.

Rakhmanov, B. K., \& Abdullaev, I. N. (2018). Problemy proizvodstva i primeneniya gruzozakhvatnykh prisposoblenii iz sinteticheskikh lent $i$ kanatov $v$ Uzbekistane. [Problems of production and use of load-gripping devices made of synthetic belts and ropes in Uzbekistan]. Pod"emnotransportnoe delo, (6), 5-7. (in Russian)

3. Yunusaliev E.M., Abdullaev I.N., Akhmedov Zh.D., Rakhmanov B.K. "Innovatsii v stroitel'noi tekhnologii: proizvodstvo i primenenie $v$ Uzbekistane strop iz tekstil'nykh lent i kombinirovannykh kanatov". [Innovations in construction technology: production and use in Uzbekistan of slings from textile belts and combined ropes.] Energoresursosberegayushchie tekhnologii i oborudovanie $v$ dorozhnoi i stroitel'noi otraslyakh. 2020. (in Russian)

4. Юнусалиев, Э. М., Абдуллаев, И. Н., Ахмедов, ж. А., \& Рахманов, Б. К. (2020). Инновации в строительной технологии: производство и применение в узбекистане строп из текстильных лент и комбинированных канатов. In Энерго-ресурсосберегающие технологии и оборудование в дорожной и строительной отраслях (pp. 421-431).

5. Shustov Yu.S., Kurdenkova A.B., Antonova O.N., Nikitina O.V. Investigations of the influence of light weather on the mechanical properties of para-aramid threads // 2007. No. 2. P.26. 
6. GOST 6611.2-73. Textile threads. Methods for determining breaking load and elongation at break.

7. Юнусалиев, Э. М., Абдуллаев, И. Н., Рахманов, Б. К., \& Алаханов, 3. М. (2020). Составные компоненты деформирования и разрушения синтетических тканых лент для грузозахватных приспособлений в строительстве. In Энергоресурсосберегающие технологии и оборудование в дорожной и строительной отраслях (рp. 431-438).

8. Абдуллаев, И. Н., \& Рахманов, Б. К. (2019). Распределение монтажных элементов зданий по массе для подбора грузозахватных синтетических строп в строительстве. In Наука и инновации в строительстве (рр. 188-192).

9. Сулейманова, Л. А., Кочерженко, В. В., Солодов, Н. В., \& Рахманов, Б. К. (2018). Перспективные направления процессов с использованием при реконструкции, ремонте. Развития технологии такелажных текстильных стропов и устранении завалов. Строительство: новые технологииновое оборудование, (12), 68-76.

10. Рахманов, Б. К., \& Алиматов, Б. А. (2018). Специальные строповочные устройства. In Наука и инновации в строительстве (рр. 264-267). 